tensa e mobilizar a organizaçâo inteira em sua procura, e como estender as fronteiras da "imaginação empresarial", revitalizando o processo da criaçâo de negócios, o que é difícil de compreender.

Os autores também ajudam a desenvolver um ponto de vista no qual "competências essenciais" podem ser construídas para o futuro. Assim, uma empresa não deverá se preocupar em lançar um produto que conquiste o mundo, mas em criar uma especie de competência que a ajude a dominar o mercado.

Em suma, a visão do futuro ajuda o patrão a enxergar a empresa como um "porta-fólio" de recursos, e não como uma coleçāo de unidades independentes, e também a mudar a organização e a criar mexcados futuros.

Paralelamente a Competindo pelo futuro, tem surgi$\mathrm{do}_{x}$ na América do Norte, novo entendimento da mentalidade empresarial e das habilidades necessárias para as organizaçōes competirem com sucesso, no século XXI. Creative destruction, de Richard L. Nolan e David C. Croson, Levers of control, de Robert Simonse Waves of change, de James L. McKenney, são livros que, ao lado do de Hamel e Prahalad - os nomes mais influentes sobre estratégia no Ocidente -, falam de questôes relativas à transformação organizacional, convidando os leitores a pensar.

De um ponto de vista mais crítico, Hamel e Prahalad indicam o óbvio. Mas as empresas hoje estato num terreno minado por modismos e verborragia. Assim, uma das qualidades da obra é ser oportuna.

Competindo pelo futuro, segundo os autores, "năo um lioro para diletintes; nâo se destina simplesmente aos intelectuais e curiosos. É um guia para os que näo se contentam em seguir a corrente, para os que acreditam que a melhor forma de wencer é reescrever as regras, para os aue não têm medo de desafiar a ortodoxia, para os que estäo mais inclinados a construir do que a eliminar, para os mais preocupados em fazer a diferença do que en desenvolver uma carreira pessoal e para os que estão absolutamente comprometidos com a vontade de chegar primeiro ao futuro".

$O$ livro está obtendo sucesso por ser importante. Para os clientes, cria produtos e serviços näo imaginados, mas que, em breve, serão essenciais. Para os executivos, cria a oportunidade de, mais que fazer carreira, deixar um legado. Para os empregados, abre vias para aspiraçóes e contribuiçóes pessoais.

Se, por um lado, Competindo pelo futuro está grandemente fundamentado na experiência, em todo o mundo, de empresas que conseguiram superar a desvantagem de recursos e galgar posiçōes de liderança mundial, por outro, as idéias otimistas de Hamel e Prahalad, claramente expostas na obra, já vêm sendo usadas por muitas organizações importantes no Primeiro Mundo.

\section{MANUAL DE SOBREVIVẾNCIA PARA SÓCIOS E HERDEIROS: A EXPERIÉNCIA DA DPZ, DO GRUPO VICUNHA, DO LABORATÓRIO FLEURY E DA MÉTODO ENGENHARIA}

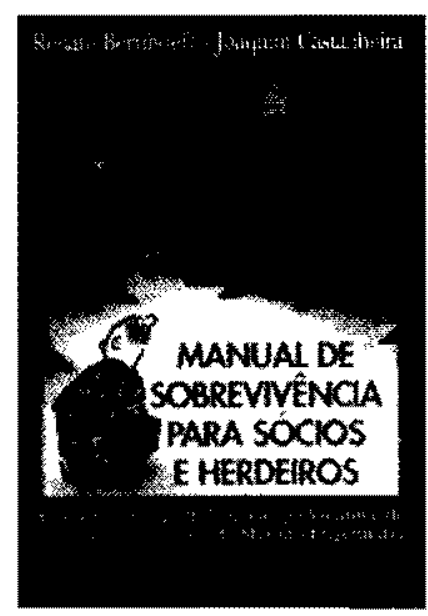

de RENATO BERNHOEFT E JOAQUIM CASTANHEIRA Säo Paulo: Nobel, 1995, 136p.

por Fabio Abilas, Graduando em Administração na Universidade Estadual de Maringá, PR.

$\mathbf{N}$ o Brasil, estima-se que a grande maioria das empresas familiares conseguem, em seu processo sucessorio, chegar somente até a terceira geração. No entanto, há casos que não chegam a esta. Os exemplos estão aî: Mattarazzo, Brandalise, Hermes Macedo etc. Problemas de sucessão, incompatibilidade de interesses, gestäo com princípios que não condizem com o pensamento do fundador, entre outros, sāo causas que desestruturam grandes grupos e deixam, no ax, perguntas e exclamaçöes como "com um império daquele?", "mas a empresa era sólida!", para as quais todos gostariam de ter respostas.

O problema é que a sucessäo familiar no Brasil é pouco discutida em termos de literatura, talvez porque algumas indústrias estejam chegando só recentemente ao seu centenário, o que torna a industrializaçâo brasileira jovem em relaçăo à dos países desenvolvidos. Mas năo se pode deixar de discutir problemas como o da preparaçăo adequada dos filhos para 
a sucessão ou do diálogo entre o empresário e seu sucessor, quando este renega esta sua condiçấo, preferindo profissões sem relação com os negócios da familia,

Nos países desenvolvidos, especialmente os europeus, mais tradicionalistas, estão expostos na parede da sala do comandante da empresa - para serem seguidas à risca pelos provăveis sucessores - códigos de ética e cartilhas de normas. O objetivo deste proce. dimento é fazer com que a empresa não perca sua identidade e suas características, mantendo as metas geradas por seus fundadores. Estas, sendo respeitadas pelos próximos sucessores, possibilitam que se tenham grandes empresas na décima quinta geração, permitindo aos negócios da família seguirem de "vento em popa".

Outro dado é que muitas empresas têm mais de um sócio, tomando o problema de sucessäo mais grave, pois existem mais pessoas reivindicando a condi̧̧ão de sucessor. Por isto, são de suma importância consultas à literatura e a pessoas especializadas na informaçäo sobre os procedimentos a serem adotados en momentos de sucessão.

Renato Bernhoeft e Joaquim Castanheira escreveram um livro digno de ser lido, pois, além da linguagem fácil e pouco especializada - um atributo facilitado pelo fato de Joaquim Castanheira ser editor da revista Exame -, as informaçōes contribuem para ampliar assuntos pouco discutidos no cenário nacional. O livro não discute somente a questão da sucessão familiar mas também a criação e manutençăo de sociedades. Hoje, ouve-se falar muito em joint-ventures e em alianças estratégicas, como se estas fossem simples de se administrar. Muitas empresas começam suas parcerias e frustram-se em vista do que encontram: empresários com temperamento exacerbado, políticas contraditórias entre as empresas, negócios pouco vantajosos para uma das partes etc.

$O$ que Bernhoeft e Castanheira tentam passar săo questöes-chave para a formaçăo e manutençäo de sociedades e para o estudo de procedimentos relacionados à sucessão familiar. Num primeiro momento, os autores apresentam situaçóes relacionadas à origem da sociedade empresarial, representadas, de forma popular, numa grande comparaçăo com o casamento. A questäo é que não se pode relacionar a sociedade de uma empresa com a sociedade conjugal. Uma é muito distinta da outra. Mesmo casais que queiram trabalhar juntos necessitam compartilhar de idéias específicas de uma empresa. É absolutamente necessária a manutençáo da identidade pessoal dos sócios, mas esta não deve estar nunca acima da identidade da empresa. Dentro de uma sociedade deve-se atingir a complementaridade. É quase impossível uma sociedade prosperar onde os sócios fazem bem a mesma coisa; cada um deve possuir qualidades diferentes que, unidas, tendem a fortalecer a organizaçäo.

Outro fator importante na sociedade é o näoenvolvimento de relacionamentos pessoais com profissionais. No segundo momento discutido no livro, os autores analisam casos de sociedades bem-sucedidas no Brasil, nos quais foram unẫnimes os depoimentos em que não há relacionamentos pessoais entre sócios. Cada um tem seus próprios amigos e freqüentam lugares diferentes. Nesta segunda parte, temse um referencial importantissimo: a experiência de empresas como DPZ, Grupo Vicunha, Laboratório Fleury e Método Engenharia. Sảo experiências que contribuem ativamente para os projetos de pessoas que pretendem abrir ou que já tèm suas sociedades. O relacionamento entre os sócios figura sempre na reciprocidade e na confiança, aspecto este fundamental na boa convivência. A partir do momento em que não há confiança entre sócios, tornam-se difíceis as relaçôes societárias.

Para complementar o assunto, os autores escrevem sobre os herdeiros das empresas familiares. Os herdeiros são caracterizados como formadores de uma sociedade imposta, por deterem uma propriedade da qual näo compartilharam o interesse de desenvolver. Sua relação com o negócio é de assumir a propriedade herdada. Muitos não têm aptidão para a gestão empresarial ou capacidade para tomar decisōes, mas mesmo assim são obrigados a manter o negócio da família, trazendo prejuizos irreparáveis para a empresa.

Bernhoeft e Castanheira enumeram algumas recomendaçöes que devem ser analisadas pelos grupos familiares. Tais recomendaçoes podem ser adotadas como um manual, pois da sua avaliaçäo depende a diminuição do risco de incompetência na sucessấo familiar.

Os autores frisam que cada empresa tem seu caso peculiar e que o livro não foi elaborado para solucionar os problemas de sociedades e sucessāo familiares. Como, no entanto, é rara a literatura sobre o assunto - e os autores săo pessoas altamente gabaritadas no cenário nacional - fica evidente que a leitura da obra é muito proveitosa para quem passa por problemas de sucessão familiar ou de manutençäo de uma sociedade. 